\title{
ІННОВАЦІЇ В СУЧАСНІЙ УКРАЇНСЬКІЙ ЕКОНОМІЧНІЙ ЛЕКСИЦІ: ЩОДО ПИТАННЯ СПЕЦИФІКИ ТЕРМІНОЛОГІЧНОГО ЗАПОЗИЧЕННЯ
}

Дьолог О. С. Інновації в сучасній українській економічній лексиці: щодо питання специфіки термінологічного запозичення.

У статті 3'ясовуються проблеми запозичення в сучасній українській термінологічній лексиці. Визначається місце англіцизмів у сучасній українській економічній термінології. Розглядаються процеси входження в мову іноземної лексики та особливості іiї вживання.

Ключові слова: інновації, термінологія, запозичення, економічна лексика, англіцизм.

Дьолог О. С. Инновации в современной экономической лексике: к вопросу о специфике терминологического заимствования.

В статье исследуются проблемы заимствования в современной украинской терминологической лексике. Определяется место англицизмов в современной украинской экономической терминологии. Рассматриваются процессы вхождения в язык иностранной лексики и особенности ее употребления.

Ключевые слова: инновации, терминология, заимствования, экономическая лексика, англицизм.

Dyolog O. S. Innovations in a modern economic vocabulary: to the question about the specific of the terminology borrowing.

In this article the problems of borrowing are probed in the modern Ukrainian

○ О. С. Дьолоґ, 2013. 
terminology vocabulary. The role of anglicizms is determined in modern Ukrainian economic terminology. The processes of included in the language of foreign vocabulary and feature of its use are examined.

Key words: innovations, terminology, borrowing, economic vocabulary, anglicism.

Запозичення в різних мовах по-різному впливають на збагачення словникового складу будь-якої мови. У деяких мовах запозичення не мають такого впливу, який міг би суттєво вплинути на їі лексичний склад. В інших мовах різні історичні епохи запозичення здійснили настільки значний вплив на словниковий склад мови, що навіть службові слова, запозичені з інших мов, витісняли питомі.

На сучасному етапі розвитку української літературної мови, коли іiі лексична система перебуває під інтенсивним чужомовним впливом, актуальною є потреба в комплексних дослідженнях численних новітніх англіцизмів. Ось чому мета даного дослідження полягає в аналізі джерел походження сучасної української економічної термінології.

Зазначена мета передбачає розв'язання таких завдань: з'ясування проблеми запозичення в сучасній українській мові і в термінологічній лексиці зокрема; визначення місця термінів-інтернаціоналізмів, запозичених 3 англійської мови, у сучасній українській економічній термінології; дослідження особливості функціонування економічних термінів-англіцизмів у сучасній українській мові.

Питання про доцільність використання запозичень взагалі пов'язано iз закріпленням лексичних засобів за певними функціональними стилями мовлення. Уживання іншомовних слів, що мають обмежену сферу поширення, може бути виправдано читацьким колом, стильовою належністю тексту.

Іншомовна термінологічна лексика $\epsilon$ незамінним засобом лаконічного і точного передавання інформації в текстах, що призначені для вузьких спеціалістів, але може виявитись нездоланною перешкодою для розуміння науково-популярного тексту непідготовленим читачем.

За умов запозичення ідей, теорій і понять зарубіжної науки вибір варіанту перекладу термінів - ключових слів тексту, основних понять наукового дослідження - також стає ключовою подією. Питання перекладу термінології, а також питання, що стосуються причин і наслідків запозичень термінів, складають актуальну проблему дослідження метамови сучасної науки.

Активізація ділових, наукових, економічних, культурних зв'язків, розквіт зарубіжного туризму в кінці XX - початку XXI століття спричинили інтенсифікацію спілкування з носіями іноземних мов.

Дослідження проблеми в лексиці та специфіки термінологічного запозичення представило всю складність процесу їі становлення i, зокрема, виявило два джерела складання терміносистеми: 1) запозичення готових термінів; 2) утворення нових термінів із матеріалу власної мови.

Ці шляхи властиві для поповнення словника загалом, але особливо чітко () О. С. Дьолоґ, 2013. 
вони виявляються у поповненні термінології, де, по-перше, значною є роль запозиченої лексики, по-друге, чіткіше проявляються процеси термінотворення, оскільки вони носять більш системний і цілеспрямований характер.

У лінгвістичній літературі існують різні позиції на питання про причини мовних змін. Одні науковці перебільшують роль екстралінгвістичних чинників, вважаючи, що всі зміни в мові зумовлені лише ними (і в першу чергу - умовами існування того суспільства, у якому існує мова). Інші науковці повністю заперечують вплив зовнішніх факторів, вважаючи, що будь-які зміни мови спричинені виключно внутрішніми причинами.

Більшість сучасних мовознавців за основу бере тезу про двобічну залежність еволюції мови від зовнішніх і внутрішніх чинників. При цьому береться до уваги, що повний опис мовної системи неможливий без урахування взаємодії екстралінгвістичних та інтралінгвістичних причин, які ще А. Мейе об'єднав у три групи: 1) структура певної мови (тобто їі будова); 2) психологічні, фізичні, просторові, соціальні та інші умови існування мови; 3) ті періодичні впливи інших мов, які у відповідний час і в певному місці відчуває відповідна мова [1, с. 96].

Розвиток окремих галузей науки відбувається нерівномірно, ось чому формування тієї чи тієї термінологічної системи визначається і особливостями розвитку даної наукової галузі. Кожна із наукових дисциплін має власний первинний момент, від якого веде свою історію іiі термінологічна мова. Велике значення при цьому мають запозичення. Вплив інших мов можна розглядати з позиції того, яка саме мова впливає на досліджувану мову i яким $є$ відповідний соціальний стан обох мов. При цьому слід звернути увагу, які саме форми приймає мовне контактування і чи залежить воно від мов, що взаємодіють. У такому розумінні вплив однієї лінгвістичної системи на іншу можна розглядати як інтралінгвістичний процес.

Розв'язання питань, пов'язаних із впливом різних мов одна на іншу, має як теоретичне, так і практичне значення. У лінгвістиці практично невідомі мови, які не стали об'єктом впливу ззовні. Процес лексичного запозичення стає особливо активним завдяки широким i різнобічним контактам між різними народами на сучасному етапі.

Запозичення 3 інших мов - природній процес, притаманний кожній розвиненій національній літературній мові, а, відповідно, й мові науки, оскільки процес формування мови науки відбувається у прямій залежності від загальних процесів розвитку національної мови.

Аналіз складу української фінансово-економічної термінології з позиції iii походження, здійснений мовознавцями, може бути представлений так:

- 19 \% фінансово-економічної термінології становлять власне українські слова (наприклад, борг, боржник, вартість, взаємозалік);

$-8 \%$ - це слова-гібриди, тобто такі, що складаються 3 двох коренів, один із яких $\epsilon$ власне українським, інший - запозиченим (наприклад, векселедавець, векселетримач, жиронаказ, жиророзрахунок); 
- 73 \% становить лексика, запозичена з різних мов світу (наприклад, офиор, рабат, рента, санація, трансферт, реверс, суборенда) [3, с. 116].

Незважаючи на широкі внутрішні можливості номінації, якими оперує кожна мова, запозичення звичайно більш розповсюджене, ніж словотвірні процеси. Це пояснюється тим, що переробити за своїм зразком і в такий спосіб засвоїти вже готову до вживання назву набагато простіше і зручніше, ніж протиставити ій власну назву того ж самого явища на підставі виділення в цьому явищі певної характерної ознаки.

Разом із зростанням кількості лексичних запозичень збільшується і науковий інтерес до їхнього вивчення. Мовознавці починають досліджувати процеси входження в мову іноземної лексики та особливості іiї вживання. Поступово накопичується спостереження над запозиченнями, збирається матеріал, що стосується взаємодії різних мов. Виникає складний комплекс питань, що стосуються проблеми запозичення. Особливої уваги набувають питання про визначення запозичень, про причини запозичень, про процес засвоєння чужих слів, про класифікацію запозичень тощо.

Варто зазначити, що в лінгвістичній літературі відзначається незначна відміна запозичення термінів від запозичення слів загального вживання. Разом із цим досвід переконує, що більшість запозичень належить до термінології, тому практично все, що зазначається про запозиченні взагалі, справедливо і для термінів.

Уже саме визначення запозичення, що дається у лінгвістичній літературі, свідчить про запозичення саме термінів. Так, «Словарь лингвистических терминов» О. С. Ахманової подає значення запозичення як «обращение к лексическому фонду других языков для выражения новых понятий, дальнейшей дифференциации уже имеющихся и обозначения неизвестных прежде предметов» [2, с. 26]. Визначення нових понять та диференціація раніше відомих притаманні для більшості запозичених термінів.

Причинами запозичення термінів $є$ не тільки потреба у визначенні нових понять, але й необхідність уточнення та покращення мовної техніки (тобто - причини власне лінгвістичного плану). До мовних причин запозичень відносять тенденцію до усунення полісемії власного слова, спрощення його смислової структури, потреби в лаконічнішому i точнішому найменуванні явища об'єктивної дійсності, що до цього передавалось описово, та необхідності уточнити відповідне поняття. Практично всі ці причини можуть застосовуватись і до термінології.

Коли ми говоримо про термін, то ми розуміємо емоційно нейтральне слово або словосполучення, яке передає назву точно зазначеного поняття, явища або предмета, що належить певній галузі науки чи техніки. Лексика такого роду дає можливості найточніше, найчіткіше, найекономніше висловити зміст і значення даного предмета та забезпечує правильне розуміння сутності самого питання.

() О. С. Дьолоґ, 2013. 
В історії формування будь-якої літературної мови важливу роль відіграє формування наукової термінології, яка забезпечує можливість активного використання літературної мови в одній із найвищих галузей спілкування - науковому спілкуванні. В історії будь-якої літературної мови $\epsilon$ період найбільш активного формування ії термінологічної системи. Для української мови - це XX століття (особливо - його початок і кінець), коли проводилась велика діяльність щодо мови наукової літератури, щодо перекладів наукових текстів, створювались еквіваленти до назв наукових понять, розширювались контакти 3 іншими мовами, які допомагали 3'ясувати семантичні можливості української мови.

Не існує загальноприйнятої класифікації запозичених слів, проте можна назвати найважливіші чинники, за якими в лінгвістичній літературі відбувається їхнє розмежування. Звичайно враховується час запозичення, мова-джерело запозичення, склад запозиченої лексики, ступінь іiї асиміляції тощо. У більшості досліджень запозиченої лексики найважливішим $\epsilon$ хронологічний аспект, за якого особлива увага приділяється часу запозичення та з'ясуванню джерела запозичення.

У сьогоднішніх дослідженнях запозиченої лексики слід враховувати тенденцію до створення міжнародної термінології, єдиних найменувань понять, явищ сучасної науки, виробництва, що також сприяє закріпленню іншомовної лексики, яка отримала інтернаціональний характер. Цей факт дає підстави вважати, що засвоєння іншомовних елементів є необхідним і обов'язковим для розвитку української мови процесом. У ставленні до запозичених слів часто протистоять дві діаметрально протилежні тенденції: з одного боку, перенасичення українського мовлення іноземними словами та зворотами, 3 іншого - повне їх заперечення і намагання вживати лише питомі українські слова.

Економічними термінами звичайно називають слова та словосполучення, що функціонують в економічній сфері і утворюють поняття економіки як науки. Сучасне життя вимагає певної обізнаності кожної пересічної людини в окремих економічних категоріях. Ось чому економічна термінологія може розглядатися (і розглядається) в сучасній лінгвістиці не тільки як маркована мова, але і як складова загальної української лексики.

Наукова українська лексика має давню історію. Проте прийнято вважати, що перший потужний поштовх у іiї розвитку належить до другої половини XIX століття. В окремих дослідженнях в галузі економічної термінології (і загальнонаукової термінології) стверджується, що саме друга половина XIX століття і $є$ власне початком ії формування [5, с. 231]. Одним iз засновників української термінології по праву вважається Іван Франко, свідченням чого $є$ його оригінальні і перекладні праці. Саме в них прозвучали вперше і закріпилися такі лексеми як: податки, промисел, иіна, вартість, доход, капітал, дивіденд, конкуренція, обмін, продаж, бухгалтерія 
та інші, що сьогодні входять до активного складу термінологічної лексики.

Українська мова, як і будь-яка інша мова світу, поступово розвивається. Розвивається при цьому i наукова лексика. На сьогодні у сучасній українській мові спостерігається збільшення кількості економічних термінів та розширення семантики вже відомих загальновживаних термінів.

У сучасній економічній термінології можна виділити дві групи лексем відповідно до використання їх у мові: 1) вузькоспеціальні терміни, які поділяються на: однослівні (наприклад, офшор, рабат, рента, санація, трансферт, реверс, суборенда); терміни-словосполучення (наприклад, біржсова изіна, ліквідні засоби, холдингова компанія); 2) загальнонаукові терміни (наприклад, проблема, ідея, гіпотеза, формула).

Неоднорідно представлена сучасна українська економічна термінологія i з позиції їі походження. Так, у сучасній мові економіки можна виділити іншомовні за походженням терміни (наприклад, корнер, лобі, менеджмент, аудит, кредит, маркетинг) та власне українські (наприклад, пропозиція, торгівля, продаж, облік). Водночас у системі економічної термінології часто можна спостерігати випадки паралельного вживання термінів-інтернаціоналізмів та власне українських термінів (наприклад, економіка - господарство, індустрія - виробництво, аукціон - торги, цесія - передавання прав).

Отже, українська економічна термінологія, формуючись на національній основі, постійно поповнюється іншомовними запозиченнями, що органічно ввійшли і продовжують входити до їі складу, поступово набуваючи при цьому ознак, притаманних для власне української лексики. У цьому разі термінологія живе за загальномовними законами, які стверджують: сила мови полягає в тому, що вона, запозичуючи необхідне чуже слово, адаптує і використовує його як власне, пристосовуючи до своїх парадигм.

На межі XX - XXI ст. активізувалися українсько-англійські мовні контакти, результатом яких стала значна кількість запозичень в українській мові в різних сферах діяльності. Не оминув цей процес i сучасну українську термінологію (зокрема - економічну).

Проте слід зазначити, це питання стосується не тільки української лексики. У даному разі українська сучасна економічна термінологія продовжує термінологічні традиції сучасних західноєвропейських мов щодо використання у своєму складі інтернаціональної лексики. Термінологія завжди прагнула до інтернаціоналізації. І це спричинило ситуацію, за якої сучасна українська економічна термінологія має велику кількість запозичень (наприклад, дисконт, аудит, менеджмент, емісія, мінімум, макроекономіка, макроструктура, синдикат, офиор, рабат, рента, санація, трансферт, реверс, суборенда тощо). Наявність таких запозичень викликана не тільки тенденцією до інтернаціоналізації сучасної української економічної термінології. Не можна не зазначити й інші (екстралінгвістичні) причини: наукові, економічні, політичні та культурні зв'язки між різними країнами світу, а значить - і між мовами.

() О. С. Дьолоґ, 2013. 
Економіка займає особливе місце серед інших суспільних наук, оскільки більше від інших пов'язана з життям народу. Звідси - тісний зв'язок економічної термінології із лексичною та стилістичною системами сучасної української літературної мови. Отже, розгляд економічної термінології як з історичної, так і з сучасної позиції підтверджує думку, що вона постійно еволюціонує і розширює свій функціональний статус. Характер змін в економічній термінології має прогресивну спрямованість, тобто є виявом тенденції до подальшого формування мови економіки.

Терміни-англіцизми мають певні зовнішні ознаки, оскільки в переважній більшості випадків зберігають фонетичні, морфологічні (а іноді навіть і графічні) риси мови-джерела. Серед основних характерних ознак термінів, запозичених з англійської мови, можемо назвати такі: 1) наявність звукосполучення дж (наприклад, бюджет, леверидж, менеджмент тощо); 2) наявність звукосполучень ай, ей (наприклад, інсайд, дизайн, аутрайт, сейф, $i$-мейл тощо); 3) наявність суфіксу -инг (-інг) (наприклад, фіксинг, кліринг, лістинг, маркетинг, блюмінг тощо).

У сучасній українській науковій лексиці трапляються окремі випадки синонімії. Взагалі, синонімія - не характерне явище для термінології. Основною ознакою терміна $\epsilon$ чіткість його значення. А синоніми в більшості випадків мають певні стилістичні або лексичні нюанси. Проте і в загальновживаній українській лексиці трапляються абсолютні синоніми, які відрізняються джерелом походження. Мова йде про одночасне використання запозиченого слова і питомого українського (наприклад, аплодисменти - оплески, екзамен іспит, лінгвістика - мовознавство тощо). Трапляються такі абсолютні синоніми і в термінології, коли одночасно використовуються термінінтернаціоналізм і власне українське слово (наприклад, аукціон-торги).

Отже, можна зазначити, що окремі поняття новітньої економічної термінології функціонують в українській мові у двох варіантах:

1) слова-інтернаціоналізми та їхні власне українські еквіваленти (наприклад, в економічних текстах і документах можна одночасно зустріти вживання слів дилер (від англ. dealer) і посередник, дефолт (від англ. default) і невиконання грошових зобов'язань, дисконт (від англ. discount) i знижка, траст (від англ. trust) і довірче товариство);

2) більшість англомовних економічних термінів не мають чіткого відповідника в українській мові і тому подаються у словниках у вигляді транслітерації з оригіналу з подальшим їхнім тлумаченням (наприклад, кредит, бартер, менеджер, ваучер тощо) .

Часто складні економічні терміни в українській мові можуть мати або дослівний переклад з оригіналу (chain of comman - ланщуюг інстанщій, span of control - норма некерованості тощо) або перекладатися описово. Це в основному стосується тих понять і реалій, які тільки зараз починають з'являтися в українському соціумі. До них належать сучасні форми 
торгівлі: one-stop environment (торговельне містечко, де можна купити будь-які товари); атрибути ведення бізнесу та ділового спілкування: short-list (остаточний список кандидатів для співбесіди під час прийому на роботу), dress code (правила, що передбачають носити певний одяг на роботі) тощо.

Деякі з сучасних американських бізнесових реалій, що вже стабільно зайняли своє місце в діловому англійському лексиконі, не знайшли відображення у двомовних англо-українських фахових словниках. Це стосується таких широко відомих у бізнесі понять, як јob objective (професія і сфера діяльності), petty cash (невелика сума готівкою для дрібних покупок), status symbols (ознаки службового становища) та ін.

Курс на інтеграцію України в СС, процес глобалізації, орієнтація на країни Заходу спричинили тісну культурну, політичну та соціальноекономічну взаємодію українців з іншими народами світу, яка не могла не відобразитися на мовному рівні, тому кількість англіцизмів сьогодні дуже швидко зростає, зокрема в українській економічній термінології.

На сучасному етапі українська економічна термінологія як частина загальноукраїнської терміносистеми відповідає вимогам міжнародних стандартів та світової наукової традиції. А бурхливий розвиток економічного життя світу та нашої країни зумовив не тільки актуальність вивчення економічних дисциплін у навчальних закладах, але і інтерес до проблем економіки на мовному рівні.

\section{Література}

1. Акуленко В. В. Українська мова в європейському контексті (проблеми розвитку мовленнєвої комунікації) / В. В.Акуленко // Мовознавство. - 2001. - № 2. - С. 91-97.

2. Ахманова О. С. Словарь лингвистических терминов: около 7000 терминов / О. С. Ахманова. - М. : Советская энциклопедия, 1969. - 608 с.

3. Бєлоусова В. Проблема кодифікації англо-американських запозичень на -ing (на матеріалі віддієслівних іменників) / В. Бєлоусова // Українська термінологія і сучасність : зб. наук. праць. - К., 1998. - С. 116-119.

4. Голдованський Я. А. Лексичні англіцизми як етимологічна група в системі мови-реципієнта / Я. А. Голдованський // Мовознавство. - 1997. - № 2. - С. 86-90.

5. Кислюк Л. П. Нові англійські запозичення і термінологія / Л. П. Кислюк // Українська термінологія. - Львів, 2006. - С. 229-236. 